\title{
High levels of maize in broiler diets with or without microbial enzyme supplementation
}

\author{
M.M. Bhuiyan, A.F. Islam \& P.A. Iji ${ }^{\#}$ \\ Department of Animal Science, School of Environmental and Rural Science, University of New England, \\ Armidale, NSW 2351, Australia
}

(Received 30 January 2012; Accepted 10 December 2012; First published online 13 March 2013)

Copyright resides with the authors in terms of the Creative Commons Attribution 2.5 South African Licence.

See: http://creativecommons.org/licenses/by/2.5/za

Condition of use: The user may copy, distribute, transmit and adapt the work, but must recognise the authors and the South African Journal of Animal Science.

\begin{abstract}
A total of 210 day-old male Cobb broiler chickens were randomly assigned to six treatments in a $3 \times 2$ factorial design. The treatments consisted of three levels of maize: $250 \mathrm{~g} / \mathrm{kg}(\mathrm{LM}), 500 \mathrm{~g} / \mathrm{kg}(\mathrm{MM})$ and 750 $\mathrm{g} / \mathrm{kg}$ diet (HM) and two levels of enzymes: plus enzyme and no enzyme. Each treatment was replicated five times, with seven birds per replicate. Chickens were reared in multi-tiered brooder cages to 21 days of age in a climate-controlled room. Feed and water were provided ad libitum. Over the feeding period (21 d), there was an increase in feed intake as maize inclusion level (MIL) increased in diets, while supplementation with microbial enzyme improved feed intake only in the MM diet. There was an improvement in live weight (LW) in chickens with increased MIL in their diets. The microbial enzyme supplement also improved LW, but only on the MM diet. The feed conversion ratio (FCR) was improved with increase in MIL in diets, but the enzyme supplements had no effect on FCR up to day 21. At day 21 there was an increase in relative weight of the small intestine with an increase in MIL, but this was not affected by enzyme supplementation. The weight of the liver increased with increase in MIL and enzyme supplementation. At day 21 the $\mathrm{pH}$ of the digesta in the gizzard declined with an increase in MIL in diets. In general, there was no significant effect of MIL or enzyme supplementation on pancreatic tissue protein content, chymotrypsin amidase activity and ileal digestibility of protein, gross energy and starch at 21 days of age. The population of Clostridium perfringens decreased significantly with increase in MIL, but other microbial species were unaffected. The present findings suggest that maize could be included at much higher levels than is currently done without detrimental effects on productivity. Exogenous enzymes also resulted in a significant increase in some of these variables.
\end{abstract}

Keywords: Maize inclusion, enzyme supplement, bird performance, gut microflora

\#Corresponding author: piji@une.edu.au

\section{Introduction}

Maize is probably the most important cereal grain used for poultry feeding around the world. It is higher in metabolizable energy than all other cereal grains and generally there is no restriction to the level of maize that can be included in the diet, provided all nutrient requirements are met. In view of its quality, it was previously thought that diets based on maize did not require microbial enzyme supplements, but more recently, responses to the inclusion of specific enzymes, particularly proteases and phytase, have been shown in maize-based diets (Saleh et al., 2006).

Microbial enzymes are now routinely included in broiler chicken diets to improve the digestion of carbohydrate, protein and mineral fractions (Bedford et al., 1991; Choct, 2006). Enzyme supplementation is more strongly required in diets containing temperate cereals such as wheat and barley owing to the high levels of viscous soluble non-starch polysaccharides (Bedford \& Morgan, 1996; Cowieson, 2005). The quality of wheat is also variable, the grain being lower in metabolizable energy content at harvest than after some period of storage (Choct \& Hughes, 1999). The inclusion of microbial enzymes in diets containing such grains has been observed to improve the nutritive value of the diets (Annison, 1992; Yang et al., 2008). 
Contrary to previous reports, maize grain has been found to vary greatly between regions of production (Cowieson \& Ravindran, 2008). These differences could probably be eliminated or reduced through microbial enzyme supplementation.

There is no consistency in the level of maize that is included in feed formulations used by the same producers or among producers. Leeson (2012) recommended modifications to the diet, to account for the drastic reduction in market age of broiler chickens (Leeson, 2012). Apart from improving nutrition in the early phase of production, there is a need to reduce feed costs in the later part of the cycle, during which feed consumption is high. Increasing grain inclusion rate in the final phases of production may achieve such effects if the diets are fortified with minerals to support adequate bone development. Such diets may also require microbial supplementation to improve carbohydrate digestion and availability of phosphorus from the increased concentration of phytase. The objectives of the current study were to assess the response of broiler chickens to rising levels of maize and effectiveness of microbial enzymes in such diets.

\section{Materials and Methods}

The experiment was a $3 \times 2$ factorial design with six dietary treatment combinations. There were three inclusion levels of maize (MIL), 250 (LM), 500 (MM) and $750 \mathrm{~g} / \mathrm{kg}$ diet (HM) and two levels of enzymes (enzyme and no enzyme). A total of 210 day-old male Cobb broiler chickens (Baiada Poultry Pty. Ltd., Kootingal, Tamworth, NSW, Australia), weighing $47.15 \pm 0.22 \mathrm{~g}$ were randomly assigned to six treatments, each with five replicates, seven chickens in each replicate. Chickens were reared in multi-tiered brooder cages $(600 \times 420 \times 23 \mathrm{~cm})$ in a climate control room up to day 21 , when the feeding trial ended. Feed and water were provided ad libitum. The room temperature was initially set at $33{ }^{\circ} \mathrm{C}$ and gradually reduced to 25 $\pm 1^{\circ} \mathrm{C}$ at 21 days. Sixteen hours of lighting per day were provided throughout the trial.

Emerald, one of the maize sources investigated in series 1 and 2, and obtained from a commercial source (2007/2008 harvest season), was used in this experiment. The diets (Table 1) were semi-purified, maize based, with or without enzyme supplementation of Avizyme $1502(0.5 \mathrm{~g} / \mathrm{kg})$ and Phyzyme XP (0.1 $\mathrm{g} / \mathrm{kg}$ ). Avizyme 1502 is an enzyme product containing purified xylanase, amylase and protease targeted at markets in which maize and sorghum are the primary energy sources used in poultry diets. Phyzyme XP is a phytase feed enzyme that improves the digestibility of phosphorus and other nutrients in cereal grains. Other dietary ingredients were Soycomil R 65\% (as protein source), vitamin mineral premix and vegetable oil. All of the experimental diets were isonitrogenous and isoenergetic. Titanium dioxide $\left(\mathrm{TiO}_{2}\right)$ was incorporated at a rate of $5 \mathrm{~g} / \mathrm{kg}$ diet as an indigestible marker, to enable assessment of nutrient digestibility.

The maize grain was ground using a hammer mill with a $4 \mathrm{~mm}$ sieve prior to mixing and the diets were given to the birds in mash form.

On days 7 and 21, two birds and four birds, respectively from each cage, were randomly selected, weighed and killed by cervical dislocation. Subsequently, the abdominal cavity was opened and the small intestine was ligated and removed. The contents of the gizzard, jejunum, ileum and caeca were collected in plastic bottles to measure $\mathrm{pH}$ or nutrient digestibility. In addition, around $1 \mathrm{~g}$ each of ileal and caecal contents were collected into pre-prepared McCartney bottles containing anaerobic broth in order to enumerate microbial populations and stored in a freezer at $-20{ }^{\circ} \mathrm{C}$ until microbial profile analyses. To determine nutrient digestibility, the digesta from the ileum were collected, pooled on a cage basis, homogenized and stored at $-20{ }^{\circ} \mathrm{C}$. Later, the samples were freeze-dried and then ground in a small coffee grinding machine and stored at $-4{ }^{\circ} \mathrm{C}$ in airtight containers for chemical analysis of $\mathrm{TiO}_{2}$, gross energy, starch and protein.

The experiment was approved by the Animal Ethics Committee of the University of New England (Approval No.: AEC 08/002). Health and animal husbandry practices complied with the Code of Practice for the Use of Animals for Scientific Purposes issued by the Australian Bureau of Animal Health (National Animal Health and Medical research Council (1990)).

Feed intake (FI) and live weight (LW) on a cage basis were recorded at weekly intervals to determine average FI and LW. Mortality was recorded as it occurred and feed conversion ratio (FCR; feed intake/weight gain) was corrected for mortality.

To assess the digestive enzyme activities and protein concentration, the jejunal tissue was processed as described by Shirazi-Beechey et al. (1991). Afterwards, sub-samples of the homogenate were taken into Eppendrof tubes (Eppendrof South Pacific, North Ryde, Australia) and stored in a freezer $\left(-20{ }^{\circ} \mathrm{C}\right)$ for enzyme analysis. The pancreas was processed in a similar manner to the jejunum, except that Milli-Q water 
(Millipore Australia, North Ryde, Australia) was used instead of mannitol-HEPES buffer and the entire tissue was homogenized. The homogenate tissue was then centrifuged at high speed (30 $000 \times \mathrm{g}$ ) for 20 minutes to obtain a supernatant on which the analysis was done (Nitsan et al., 1974).

The specific activities of jejunal and pancreatic enzymes were assessed by incubation with fixed substrate concentrations as standardized for poultry by Iji et al. (2001). On the jejunal homogenates, the assays were conducted for mucosal protein content and activities of alkaline phosphatase (EC 3.1.3.1), maltase (EC 3.2.1.20) and sucrase (EC 3.2.1.10). For the pancreas, an assay was conducted for chymotrypsin amidase (EC 3.4.21.1). The specific activities of enzymes were measured according to the methods previously described for other species (Serviere-Zaragoza et al., 1997) after standardization for poultry. The concentration of protein in both the jejunal mucosa and pancreatic tissue was measured using the Coomassie dye-binding procedure described by Bradford (1976). All of the raw data for protein concentration were processed through the Lowry Software (Mcpherson, 1985) before statistical analysis.

Table 1 Composition of experimental diets (g/kg)

\begin{tabular}{|c|c|c|c|c|c|c|}
\hline \multirow{2}{*}{ Ingredients } & \multicolumn{2}{|c|}{ LM } & \multicolumn{2}{|c|}{ MM } & \multicolumn{2}{|c|}{ HM } \\
\hline & Diet 1 & Diet 2 & Diet 3 & Diet 4 & Diet 5 & Diet 6 \\
\hline Maize & 250.0 & 250.0 & 500.0 & 500.0 & 750.0 & 750.0 \\
\hline Soycomill R 65\% & 289.0 & 289.0 & 252.0 & 252.0 & 212.0 & 212.0 \\
\hline Maize starch & 419.0 & 419.0 & 210.6 & 210.6 & 0.0 & 0.0 \\
\hline Choline chloride & 1.0 & 1.0 & 1.0 & 1.0 & 13.0 & 13.0 \\
\hline Sodium bicarbonate & 1.0 & 1.0 & 1.0 & 1.0 & 17.0 & 17.0 \\
\hline Limestone & 13.0 & 13.0 & 13.0 & 13.0 & 1.0 & 1.0 \\
\hline Dicalcium phosphate & 15.0 & 15.0 & 15.0 & 15.0 & 1.8 & 1.8 \\
\hline Salt & 3.0 & 3.0 & 3.0 & 3.0 & 1.5 & 1.5 \\
\hline L-Lysine & 0.1 & 0.1 & 0.9 & 0.9 & 3.0 & 3.0 \\
\hline DL Methionine & 1.9 & 1.9 & 1.7 & 1.7 & 1.0 & 1.0 \\
\hline Titanium dioxide & 5.0 & 5.0 & 5.0 & 5.0 & 5.0 & 5.0 \\
\hline Vitamin-mineral premix ${ }^{1}$ & 2.0 & 2.0 & 2.0 & 2.0 & 2.0 & 2.0 \\
\hline Avizyme 1502 & 0 & 0.5 & 0 & 0.5 & 0 & 0.5 \\
\hline Phyzyme XP & 0 & 0.1 & 0 & 0.1 & 0 & 0.1 \\
\hline \multicolumn{7}{|l|}{ Nutrient composition (g/kg) } \\
\hline ME poultry (MJ/kg) & 13.0 & 13.0 & 12.9 & 12.9 & 12.8 & 12.8 \\
\hline Crude Protein & 212.0 & 212.0 & 212.0 & 212.0 & 209.0 & 209.0 \\
\hline Lysine & 13.0 & 13.0 & 12.9 & 12.9 & 12.8 & 12.8 \\
\hline Methionine & 5.0 & 5.0 & 5.0 & 5.0 & 4.9 & 4.9 \\
\hline Arginine & 13.1 & 13.0 & 12.9 & 13.2 & 13.4 & 12.9 \\
\hline Methionine+cystine & 7.4 & 7.5 & 7.9 & 8.1 & 8.2 & 7.8 \\
\hline Histidine & 3.8 & 3.9 & 4.1 & 3.8 & 3.9 & 4.2 \\
\hline Threonine & 8.7 & 8.7 & 8.5 & 8.5 & 8.2 & 8.2 \\
\hline Calcium & 10.0 & 10.0 & 10.0 & 10.0 & 9.9 & 9.9 \\
\hline Available phosphorus & 4.0 & 4.0 & 4.1 & 4.1 & 4.2 & 4.2 \\
\hline Sodium & 1.8 & 1.9 & 2.0 & 1.9 & 2.0 & 1.8 \\
\hline Choline & 1.6 & 1.5 & 1.7 & 1.5 & 1.6 & 1.5 \\
\hline
\end{tabular}

${ }^{1}$ Supplied per kg of diet (mg): $3.6 \mathrm{mg}$ vitamin A (as all-trans retinol); $0.09 \mathrm{mg}$ cholecalciferol; ), $44.7 \mathrm{mg}$ vitamin E (as $\mathrm{d}$ - $\alpha$-tocopherol); $2 \mathrm{mg}$ vitamin $\mathrm{K}_{3} ; 2 \mathrm{mg}$ thiamine; $6 \mathrm{mg}$ riboflavin; $5 \mathrm{mg}$ pyridoxine hydrochloride; $0.2 \mathrm{mg}$ vitamin $\mathrm{B}_{12}$; $0.1 \mathrm{mg}$ biotin; $50 \mathrm{mg}$ niacin; $12 \mathrm{mg}$ D-calcium pantothenate; $2 \mathrm{mg}$ folic acid; $80 \mathrm{mg} \mathrm{Mn;} 60 \mathrm{mg}$ Fe; $8 \mathrm{mg} \mathrm{Cu} 11 \mathrm{mg} \mathrm{I}$; $0.3 \mathrm{mg} \mathrm{Co} ; 1 \mathrm{mg}$ Mo.

Inclusion level of maize: LM: 250 g/kg; MM: 500 g/kg; 750 g/kg. 
The $\mathrm{TiO}_{2}$ content of the digesta and diet samples was measured according to the method of Short et al. (1996). The concentration of protein, gross energy and starch in feed and freeze-dried ileal digesta were analyzed along with the indigestible titanium dioxide marker, and was used to calculate the digestibility coefficient. Diets and ileal digesta were analysed for protein, gross energy and starch according to AOAC (2002). The digestibility coefficient for nutrients was calculated using the following equation:

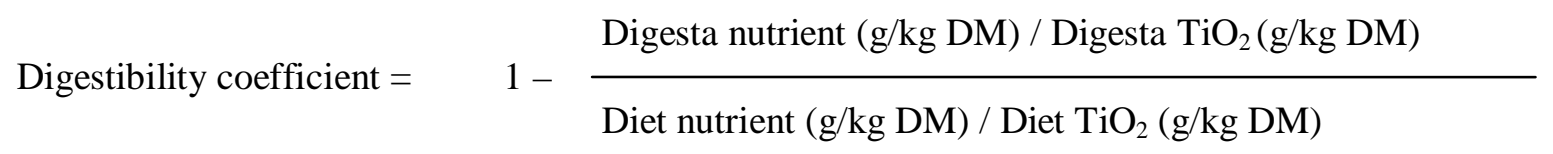

Gut microbial populations were enumerated in digesta contents of the ileum and caeca at 21 days of age, according to the procedure described by Engberg et al. (2004) and Miller \& Wolin (1974) and highlighted below. Fresh intestinal contents, weighing around $1 \mathrm{~g}$, from the ileum and caeca were transferred into $15 \mathrm{~mL}$ MacCartney bottles containing $10 \mathrm{~mL}$ of anaerobic broth and used to assess microbial profiles.

Lactic acid bacteria were enumerated on MRS agar (Oxoid, CM0361) incubated under anaerobic conditions at $39{ }^{\circ} \mathrm{C}$ for $48 \mathrm{~h}$. Coliform (red colonies) and lactose-negative Enterobacteria (colourless colonies) were counted on MacConkey agar (Oxoid, CM 0007) incubated aerobically at $39{ }^{\circ} \mathrm{C}$ for $24 \mathrm{~h}$ as red and colourless colonies, respectively. Lactobacilli were enumerated on Rogossa agar (Oxoid, CM 0627) after anaerobic incubation at $39^{\circ} \mathrm{C}$ for $48 \mathrm{~h}$. Total anaerobic bacteria were counted using anaerobic roll tubes containing $3 \mathrm{~mL}$ of Wilkins-Chalgren anaerobic agar (Oxoid, CM 0619) incubated at $39{ }^{\circ} \mathrm{C}$ for 7 days. Numbers of Clostridium perfringens were counted on tryptose-sulphite-cycloserine and Shahidi-Ferguson Perfringens agar base (TSC and SFP) (Oxoid, CM 0587 OPSP) mixed with egg yolk emulsion (Oxoid, SR0047) and Perfringens (TSC) selective supplement (Oxoid, SR0088E) according to the pour-plate technique, where plates were overlaid with the same agar after spreading the inoculum and incubated anaerobically at $39^{\circ} \mathrm{C}$ for $24 \mathrm{~h}$. An anaerobic AnaeroGen ${ }^{\mathrm{TM}}$ sachet (AN0025A, Oxoid Ltd, Hampshire, UK) was used to generate the anaerobic environment $\left(<1 \% \mathrm{O}_{2}\right.$ and $9 \%$ to $\left.13 \% \mathrm{CO}_{2}\right)$ for all anaerobically incubated agar plates.

The enumeration of microbial profiles was conducted only on chickens raised on diets containing fine hammer-milled and coarse roller-milled grains. This was done mainly to reduce the number of replicates that were analysed but the groups were chosen to reflect differences in particle size and milling techniques. Roller milling at a coarse setting resulted in almost an equal balance in particle size, while hammer milling at a fine setting yielded predominantly fine particles. After incubation, colonies formed on the respective media were carefully counted, converted into logarithmic equivalents $\left(\log _{10}\right)$ and expressed as number of colony forming units (CFU) per gram of wet intestinal content.

Data were analysed using the multiple regression options of SPSS, version 17.0.0 (SPSS Inc 2009) for the main effects of increasing MIL and enzyme supplementation (Morris, 1998). Data were also subjected to GLM analysis and reported where there was an interaction between MIL and microbial enzyme supplementation. Separation of means within a significant effect was done by Duncan's multiple range test (DMRT) through the post hoc procedure of SPSS. Significance levels were set at $P \leq 0.05$ unless otherwise specified.

\section{Results}

Bird performance was generally poor in the current study, with live weight considerably below the breeder specification. This could have been caused by a reduction in feed consumption, probably owing to the nature of the diets, especially with high levels of starch and a purified protein concentrate. Up to 7 days of age there was a decline $\left(P<0.001, \mathrm{R}^{2}=0.56\right)$ in feed intake as maize inclusion level (MIL) rose in the diets (Table 2). However, FI increased $\left(P<0.007, \mathrm{R}^{2}=0.56\right)$ with the inclusion of enzymes only on the LM diet. There was an increase in live weight with an increase in MIL $\left(P<0.001, \mathrm{R}^{2}=0.41\right)$ in diets and with the addition of microbial enzyme supplement $\left(P<0.047, \mathrm{R}^{2}=0.41\right)$. Overall, there was no significant response in LW to changes in MIL with or without microbial enzyme supplement in early life. Up to this age, the FCR of the chicks was improved $\left(P<0.001, \mathrm{R}^{2}=0.61\right)$ as MIL increased in the diets, while enzyme supplementation had no effect. 
There was an increase $\left(P<0.001, \mathrm{R}^{2}=0.57\right)$ in feed intake to $21 \mathrm{~d}$ as MIL increased in diets, while supplementation with microbial enzyme $\left(P<0.007, \mathrm{R}^{2}=0.57\right)$ improved feed intake, but only on the MM diet (Table 3). The interaction between MIL and enzyme on FI was significant $(P<0.050)$.

There was an improvement $\left(P<0.001, \mathrm{R}^{2}=0.71\right)$ in LW in chickens with increase in MIL in diets. The microbial enzyme supplement also improved $\left(P<0.004, \mathrm{R}^{2}=0.71\right) \mathrm{LW}$, but only on the MM diet. The interaction between MIL and enzyme on LW was significant $(P<0.020)$. The FCR was improved $(P<0.001$, $\left.\mathrm{R}^{2}=0.42\right)$ in chickens with increase in MIL in diets, but the enzyme supplements had no effect on FCR up to day 21.

At day 21 there was an increase $\left(P<0.01, \mathrm{R}^{2}=0.26\right)$ in relative weight of the small intestine with an increase in MIL, but this was not affected by the enzyme supplement (Table 4). There was no significant change in the relative weight of the pancreas because of an increase in MIL in diets with or without enzyme supplements at this age. There was an increase $\left(P<0.03, \mathrm{R}^{2}=0.31\right)$ in relative weight of the liver with increase in MIL in diets, while enzyme supplementation enhanced $\left(P<0.02, \mathrm{R}^{2}=0.31\right)$ liver weight only on the MM diet. The relative weight of the proventriculus plus gizzard increased $\left(P<0.01, \mathrm{R}^{2}=0.27\right)$ with a rise in MIL in diets, but there was no effect of enzyme supplementation on the weight of these organs. There was no significant change in the relative weight of spleen with increase in MIL in diets, with or without enzyme supplement. However, there was an increase $\left(P<0.05, \mathrm{R}^{2}=0.15\right)$ in the relative weight of bursa of Fabricius with the addition of microbial enzymes in diets, but no significant effect of MIL in diets.

Table 2 Feed intake (FI), live weight (LW) and feed conversion ratio (FCR) of broiler chickens at day 7 at various maize inclusion levels (MIL) with or without microbial enzyme supplementation ${ }^{1}$

\begin{tabular}{|c|c|c|c|c|}
\hline \multicolumn{2}{|c|}{ Treatments } & \multirow{2}{*}{ FI (g/bird) } & \multirow{2}{*}{ LW (g/bird) } & \multirow{2}{*}{ FCR (g:g) } \\
\hline MIL (g/kg) & Enzyme & & & \\
\hline \multirow[t]{2}{*}{250} & - & $79.0^{\mathrm{b}}$ & $98.8^{\mathrm{b}}$ & $1.62^{\mathrm{a}}$ \\
\hline & + & $91.6^{\mathrm{a}}$ & $110.0^{\mathrm{ab}}$ & $1.47^{\mathrm{a}}$ \\
\hline \multirow[t]{2}{*}{500} & - & $71.3^{\mathrm{bc}}$ & $112.2^{\mathrm{a}}$ & $1.11^{\mathrm{b}}$ \\
\hline & + & $78.8^{\mathrm{b}}$ & $121.0^{\mathrm{a}}$ & $1.06^{\mathrm{b}}$ \\
\hline \multirow[t]{2}{*}{750} & - & $68.7^{c}$ & $119.3^{\mathrm{a}}$ & $0.96^{\mathrm{b}}$ \\
\hline & + & $71.0^{\mathrm{bc}}$ & $119.4^{\mathrm{a}}$ & $0.98^{\mathrm{b}}$ \\
\hline Pooled SEM & & 1.83 & 2.03 & 0.06 \\
\hline Model $P$ & & $<0.001$ & $<0.004$ & $<0.001$ \\
\hline \multicolumn{5}{|c|}{ Source of variation } \\
\hline MIL & & $<0.001$ & $<0.001$ & $<0.001$ \\
\hline Enzyme & & $<0.007$ & $<0.047$ & NS \\
\hline
\end{tabular}

${ }^{\mathrm{T}}$ Each value represents the mean of five replicates for each treatment group; ${ }^{\mathrm{a}, \mathrm{b}, \mathrm{c}}$ Values with unlike superscripts within each column are significantly different $(P<0.05)$; NS: non-significant; SEM: standard error of mean.

At 21 days of age the $\mathrm{pH}$ of the digesta in the gizzard declined $\left(P<0.01, \mathrm{R}^{2}=0.22\right)$ with an increase in MIL in diets (Table 5). However, the $\mathrm{pH}$ of the gizzard content was not changed by enzyme supplementation. The $\mathrm{pH}$ value of the jejunal content marginally declined $\left(P<0.07, \mathrm{R}^{2}=0.18\right)$ with an increase in MIL in diets. There was no significant change in the $\mathrm{pH}$ value of digesta in ileum with an increase in MIL, with or without the enzyme supplements. There was an increase in the $\mathrm{pH}$ of the digesta in the caeca with increase in MIL $\left(P<0.02, \mathrm{R}^{2}=0.34\right)$ in the diets. The microbial enzyme supplement also enhanced $\left(P<0.01, \mathrm{R}^{2}=0.34\right)$ the $\mathrm{pH}$ value of caecal content but only on the HM diet. 
Table 3 Feed intake (FI), live weight (LW) and feed conversion ratio (FCR) of broiler chickens at day 21 at various maize inclusion levels (MIL) with or without microbial enzyme supplementation ${ }^{1}$

\begin{tabular}{|c|c|c|c|c|}
\hline \multicolumn{2}{|c|}{ Treatments } & \multirow{2}{*}{ FI (g/bird) } & \multirow{2}{*}{ LW (g/bird) } & \multirow{2}{*}{ FCR (g:g) } \\
\hline MIL (g/kg) & Enzyme & & & \\
\hline \multirow[t]{2}{*}{250} & - & $642.5^{\mathrm{b}}$ & $426.5^{\mathrm{c}}$ & $1.70^{\mathrm{a}}$ \\
\hline & + & $726.8^{\mathrm{ab}}$ & $489.8^{\mathrm{bc}}$ & $1.64^{\mathrm{ab}}$ \\
\hline \multirow[t]{2}{*}{500} & - & $706.6^{\mathrm{b}}$ & $506.6^{\mathrm{b}}$ & $1.54^{\mathrm{bc}}$ \\
\hline & + & $814.0^{\mathrm{a}}$ & $583.8^{\mathrm{a}}$ & $1.52^{\mathrm{c}}$ \\
\hline \multirow[t]{2}{*}{750} & - & $824.8^{\mathrm{a}}$ & $594.0^{\mathrm{a}}$ & $1.51^{\mathrm{c}}$ \\
\hline & + & $815.1^{\mathrm{a}}$ & $586.9^{\mathrm{a}}$ & $1.51^{\mathrm{c}}$ \\
\hline \multicolumn{2}{|c|}{ Pooled SEM } & 15.47 & 12.83 & 0.02 \\
\hline \multicolumn{2}{|c|}{ Model $P$} & $<0.001$ & $<0.001$ & $<0.003$ \\
\hline \multicolumn{5}{|c|}{ Source of variation } \\
\hline \multicolumn{2}{|c|}{ MIL } & $<0.001$ & $<0.001$ & $<0.001$ \\
\hline \multicolumn{2}{|c|}{ Enzyme } & $<0.007$ & $<0.004$ & NS \\
\hline \multicolumn{2}{|c|}{ MIL $\times$ enzyme } & $<0.050$ & $<0.020$ & NS \\
\hline
\end{tabular}

Table 4 Relative weight of small intestine, proventriculus-gizzard, pancreas, liver spleen and bursa (g/100 g of body weight) of broiler chickens at day 21 at various maize inclusion levels (MIL) with or without microbial enzyme supplementation ${ }^{1}$

\begin{tabular}{|c|c|c|c|c|c|c|c|}
\hline \multicolumn{2}{|c|}{ Treatments } & \multirow{2}{*}{$\begin{array}{l}\text { Small } \\
\text { intest }^{2}\end{array}$} & \multirow{2}{*}{ Pancreas } & \multirow{2}{*}{ Liver } & \multirow{2}{*}{$\begin{array}{l}\text { Pro+ } \\
\text { Gizz }^{3}\end{array}$} & \multirow{2}{*}{ Spleen } & \multirow{2}{*}{ Bursa } \\
\hline MIL (g/kg) & Enzyme & & & & & & \\
\hline \multirow[t]{2}{*}{250} & - & 5.4 & 0.30 & $2.8^{\mathrm{c}}$ & $4.1^{\mathrm{b}}$ & 0.09 & 0.16 \\
\hline & + & 5.5 & 0.35 & $3.0^{\mathrm{c}}$ & $4.1^{\mathrm{b}}$ & 0.10 & 0.20 \\
\hline \multirow[t]{2}{*}{500} & - & 5.9 & 0.33 & $3.3^{c}$ & $4.6^{\mathrm{ab}}$ & 0.08 & 0.17 \\
\hline & + & 6.5 & 0.32 & $4.1^{\mathrm{a}}$ & $5.1^{\mathrm{a}}$ & 0.09 & 0.20 \\
\hline \multirow[t]{2}{*}{750} & - & 6.3 & 0.33 & $3.1^{\mathrm{c}}$ & $4.6^{\mathrm{ab}}$ & 0.10 & 0.18 \\
\hline & + & 6.8 & 0.37 & $4.0^{\mathrm{bc}}$ & $5.1^{\mathrm{a}}$ & 0.10 & 0.22 \\
\hline \multicolumn{2}{|c|}{ Pooled SEM } & 0.18 & 0.01 & 0.14 & 0.13 & 0.00 & 0.01 \\
\hline \multicolumn{2}{|c|}{ Model $P$} & NS & NS & $<0.01$ & $<0.04$ & NS & NS \\
\hline \multicolumn{8}{|c|}{ Source of variation } \\
\hline \multicolumn{2}{|c|}{ MIL } & $<0.01$ & NS & $<0.03$ & $<0.01$ & NS & NS \\
\hline \multicolumn{2}{|c|}{ Enzyme } & NS & NS & $<0.02$ & NS & NS & $<0.05$ \\
\hline
\end{tabular}

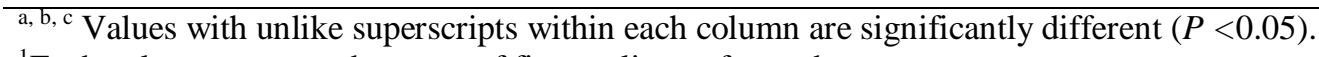

${ }^{1}$ Each value represents the mean of five replicates for each treatment group.

${ }^{2}$ Small intestine with digesta; ${ }^{3}$ Proventriculus plus gizzard with digesta.

NS: non-significant; SEM: standard error of mean.

At 21 days of age there was no significant change in pancreatic tissue protein content and chymotrypsin amidase activity with increase in MIL in diets, with or without enzyme supplement (Table 6). 
However, the protein content, as well as the activity of chymotrypsin amidase, tended to decrease with an increase in MIL, while the activity of chymotrypsin amidase was slightly increased in birds on the enzymesupplemented diets. There was no significant change in tissue protein content and alkaline phosphatase activity in the jejunum, but these tended to decline as MIL increased in diets. The activity of alkaline phosphatase marginally increased in birds fed on diets with enzyme supplementation, but not significantly.

In general, there was no significant effect of MIL or enzyme supplementation on ileal digestibility of protein, gross energy and starch at 21 days of age (Table 7). However, digestibility slightly increased as MIL rose in diet and with exogenous enzyme inclusion.

There was no significant change in the population of various types of bacteria in ileal contents with increase in MIL in diets with or without enzyme supplement at 21 days of age (Table 8). Nevertheless, the number of $C$. perfringens decreased $\left(P<0.05, \mathrm{R}^{2}=0.32\right)$ with increase in MIL in diets. However, the population of this species was marginally increased $\left(P<0.07, \mathrm{R}^{2}=0.32\right)$ with the addition of microbial enzyme. In addition, the numbers of lactic acid bacteria marginally decreased with increase in MIL, while all bacterial populations increased with the inclusion of exogenous enzyme. However, these differences were not statistically significant. There was no significant change in the population of the various bacteria in caecal content as a result of an increase in MIL in diets with or without the enzyme supplement (Table 8). However, these bacterial populations slightly decreased on the enzyme-supplemented diets.

Table 5 PH values of small intestinal content of broiler chickens at day 21 at various maize inclusion levels (MIL) with or without microbial enzyme supplementation ${ }^{1}$

\begin{tabular}{|c|c|c|c|c|c|}
\hline \multicolumn{2}{|c|}{ Treatments } & \multirow{2}{*}{ Gizzard } & \multirow{2}{*}{ Jejunum } & \multirow{2}{*}{ Ileum } & \multirow{2}{*}{ Caecum } \\
\hline MIL (g/kg) & Enzyme & & & & \\
\hline \multirow[t]{2}{*}{250} & - & 3.3 & 6.4 & 7.3 & $7.2^{\mathrm{d}}$ \\
\hline & + & 3.2 & 6.6 & 7.5 & $7.5^{\mathrm{bcd}}$ \\
\hline \multirow[t]{2}{*}{500} & - & 3.0 & 6.4 & 7.2 & $7.8^{\mathrm{abc}}$ \\
\hline & + & 3.1 & 6.4 & 7.1 & $7.9^{\mathrm{ab}}$ \\
\hline \multirow[t]{2}{*}{750} & - & 2.8 & 6.3 & 7.3 & $7.4^{\mathrm{cd}}$ \\
\hline & + & 3.0 & 6.4 & 7.1 & $8.2^{\mathrm{a}}$ \\
\hline \multicolumn{2}{|c|}{ Pooled SEM } & 0.06 & 0.03 & 0.08 & 0.08 \\
\hline \multicolumn{2}{|c|}{ Model $P$} & NS & NS & NS & $<0.01$ \\
\hline \multicolumn{6}{|c|}{ Source of variation } \\
\hline \multicolumn{2}{|c|}{ MIL } & $<0.01$ & 0.07 & NS & $<0.02$ \\
\hline \multicolumn{2}{|c|}{ Enzyme } & NS & NS & NS & $<0.01$ \\
\hline
\end{tabular}

${ }^{1}$ Each value represents the mean of five replicates for each treatment group.

a, b, c, d Values with unlike superscripts within each column are significantly different $(P<0.05)$.

NS: non-significant; SEM: standard error of mean.

\section{Discussion}

The results of this experiment demonstrate no detrimental effects of very high levels of maize on feed intake or growth. Addition of enzyme improved overall productivity on some of the diets. The response to the enzymes is in agreement with the results of Cafe et al. (2002), who found a significant improvement in body weight of male broilers at different ages with a nutritionally adequate broiler diet based on maize and soybean meal with supplementation of Avizyme. Shakouri et al. (2008) reported a similar positive effect of supplemental enzyme on the performance of broiler chickens fed on a wheat-based diet. However, results from the current study contrast with the findings of Fathabadi et al. (2006), who did not observe any significant effect of Avizyme 1502 on FI, LW and LWG, but improved FCR was recorded in Hubbard 
Classic chickens. Maize may respond to carbohydrase enzyme supplementation owing to the presence of non-starch polysaccharides, a large part of which is arabinose and xylose (Chesson, 2001).

Organ weight data revealed that inclusion of maize at high level increased the size/volume of the small intestine and liver, leading to improved digestive activity. Enzyme addition also increased the size of liver.

Table 6 Tissue protein content and enzyme activities of broiler chickens at day 21 at various maize inclusion levels (MIL) with or without microbial enzyme supplementation ${ }^{1}$

\begin{tabular}{|c|c|c|c|c|c|}
\hline \multicolumn{2}{|c|}{ Treatments } & \multicolumn{2}{|c|}{ Pancreas } & \multicolumn{2}{|c|}{ Jejunum } \\
\hline MIL (g/kg) & Enzyme & $\begin{array}{c}\text { Protein } \\
\text { (mg/g tissue) }\end{array}$ & $\begin{array}{c}\text { Chymotrypsin } \\
\text { amidase }^{2}\end{array}$ & $\begin{array}{c}\text { Protein } \\
\text { (mg/g tissue) }\end{array}$ & $\begin{array}{c}\text { Alkaline } \\
\text { phosphatase }^{3}\end{array}$ \\
\hline \multirow[t]{2}{*}{250} & - & 69.5 & 7.6 & 385.6 & 4.7 \\
\hline & + & 70.9 & 6.8 & 350.7 & 5.6 \\
\hline \multirow[t]{2}{*}{500} & - & 53.5 & 7.3 & 319.8 & 4.2 \\
\hline & + & 61.0 & 6.3 & 304.8 & 5.1 \\
\hline \multirow[t]{2}{*}{750} & - & 64.5 & 5.1 & 324.9 & 5.0 \\
\hline & + & 59.1 & 6.4 & 346.2 & 5.3 \\
\hline \multicolumn{2}{|c|}{ Pooled SEM } & 3.81 & 0.001 & 10.05 & 0.46 \\
\hline \multicolumn{2}{|c|}{ Model $P$} & NS & NS & NS & NS \\
\hline \multicolumn{6}{|c|}{ Source of variation } \\
\hline \multicolumn{2}{|c|}{ MIL } & NS & NS & NS & NS \\
\hline \multicolumn{2}{|c|}{ Enzyme } & NS & NS & NS & NS \\
\hline
\end{tabular}

${ }^{\mathrm{T}}$ Each value represents the mean of five replicates for each treatment group.

${ }^{2}$ Specific activity $(\eta \mathrm{mol} / \mathrm{mg}$ protein $/ \mathrm{min}) ;{ }^{3}$ Specific activity $(\mu \mathrm{mol} / \mathrm{mg}$ protein $/ \mathrm{min})$.

NS: non-significant; SEM: standard error of mean.

Table 7 Protein, gross energy and starch digestibility of broiler chickens at day 21 at various maize inclusion levels (MIL) with or without microbial enzyme supplementation ${ }^{1}$

\begin{tabular}{|c|c|c|c|c|}
\hline \multicolumn{2}{|c|}{ Treatments } & \multirow{2}{*}{ Protein } & \multirow{2}{*}{ Gross energy } & \multirow{2}{*}{ Starch } \\
\hline MIL (g/kg) & Enzyme & & & \\
\hline \multirow[t]{2}{*}{250} & - & 0.82 & 0.79 & 0.97 \\
\hline & + & 0.84 & 0.82 & 0.99 \\
\hline \multirow[t]{2}{*}{500} & - & 0.81 & 0.78 & 0.96 \\
\hline & + & 0.84 & 0.79 & 0.98 \\
\hline \multirow[t]{2}{*}{750} & - & 0.86 & 0.82 & 0.98 \\
\hline & + & 0.86 & 0.84 & 0.99 \\
\hline \multicolumn{2}{|c|}{ Pooled SEM } & 0.008 & 0.011 & 0.004 \\
\hline & & NS & NS & NS \\
\hline \multicolumn{5}{|c|}{ Source of variation } \\
\hline \multicolumn{2}{|c|}{ MIL } & NS & NS & NS \\
\hline \multicolumn{2}{|c|}{ Enzyme } & NS & NS & NS \\
\hline
\end{tabular}

${ }^{1}$ Each value represents the mean of five replicates for each treatment group.

NS: non-significant; SEM: standard error of mean. 
Table 8 Bacterial counts ( $\log _{10}$ cfu /g digesta) in ileum and caecum sections of digestive tract of broiler chickens given different levels of maize grain with or without enzyme-based diet fed as mash at day $21^{1}$

\begin{tabular}{|c|c|c|c|c|c|c|c|c|c|c|c|}
\hline \multicolumn{2}{|c|}{ Treatments } & \multicolumn{5}{|c|}{ Ileal content } & \multicolumn{5}{|c|}{ Caecal content } \\
\hline MIL (g/kg) & Enzyme & $\begin{array}{c}\text { Anaero- } \\
\text { bic }\end{array}$ & $\begin{array}{c}\text { Lactic } \\
\text { acid }\end{array}$ & $\begin{array}{l}\text { Lacto- } \\
\text { bacilli }\end{array}$ & $\begin{array}{c}\text { Entero } \\
\text { bacteria }\end{array}$ & $\begin{array}{c}C . \\
\text { perfringens } \\
\end{array}$ & $\begin{array}{c}\text { Anaero- } \\
\text { bic }\end{array}$ & $\begin{array}{c}\text { Lactic } \\
\text { acid } \\
\end{array}$ & $\begin{array}{l}\text { Lacto- } \\
\text { bacilli }\end{array}$ & $\begin{array}{c}\text { Entero } \\
\text { bacteria }\end{array}$ & $\begin{array}{c}C . \\
\text { perfringens } \\
\end{array}$ \\
\hline \multirow[t]{2}{*}{250} & - & 7.7 & 7.9 & 7.7 & 4.9 & 4.3 & 7.7 & 7.3 & 7.2 & 6.3 & 5.2 \\
\hline & + & 7.3 & 7.4 & 7.2 & 4.5 & 4.1 & 9.1 & 8.9 & 8.5 & 8.1 & 6.0 \\
\hline \multirow[t]{2}{*}{750} & - & 7.4 & 7.6 & 7.6 & 5.0 & 4.1 & 9.2 & 9.0 & 8.8 & 8.1 & 6.3 \\
\hline & + & 7.7 & 7.5 & 7.4 & 4.4 & 3.9 & 9.2 & 9.0 & 8.9 & 7.9 & 5.4 \\
\hline \multicolumn{2}{|c|}{ Pooled SEM } & 0.10 & 0.11 & 0.10 & 0.16 & 0.06 & 0.47 & 0.46 & 0.45 & 0.44 & 0.37 \\
\hline \multicolumn{2}{|c|}{ Model P } & NS & NS & NS & NS & 0.091 & NS & NS & NS & NS & NS \\
\hline \multicolumn{12}{|c|}{ Source of variation } \\
\hline \multicolumn{2}{|c|}{ MIL } & NS & NS & NS & NS & $<0.05$ & NS & NS & NS & NS & NS \\
\hline \multicolumn{2}{|c|}{ Enzyme } & NS & NS & NS & NS & $<0.07$ & NS & NS & NS & NS & NS \\
\hline
\end{tabular}

${ }^{1}$ Each value represents the mean of five replicates for each treatment group.

NS: non-significant; SEM: standard error of mean. 
The relative weights of the major digestive and immune organs were affected by MIL and enzyme supplementation. The significant enlargement of the small intestine and proventriculus/gizzard of birds on the higher MIL may be partly attributed to the influence of grain texture, resulting in stimulation of the digestive organs. This finding is in agreement with that of Zarghi \& Golian (2009), who reported an increase in the weight of the gizzard and small intestine with an increase in triticale in the diet when measured at 18 and 42 days of age.

In this study the MIL or enzyme supplementation had no effect on pancreatic and jejunal tissue protein content or mucosal digestive enzyme activities of the birds. Intestinal enzyme activities are stimulated by chyme passing through the digestive tract (Duke, 1986). In a previous study on broiler chickens, Jiang et al. (2008) found an increased activity of trypsin within the intestinal lumen, while lipase, pancreatic protease and trypsin activities were not affected by exogenous amylase. The slight reduction in jejunal protein content owing to supplementation with microbial enzymes is in agreement with the findings of other researchers (Iji et al., 2004) and may have a positive effect on the use of nutrients.

It is generally known that the addition of exogenous enzymes to wheat- and maize-based diets increases digestibility of nutrients in broiler chickens (Scott et al., 2003). However, in the current study there were no significant changes in ileal nutritient digestibility owing to MIL or enzyme supplementation or their interactions in broiler chicken at 21 days of age. Nevertheless, the digestibility of CP and gross energy were slightly increased on the HM diet, but not the lower MIL diets. Cowieson et al. (2006) suggested that the digestibility of nutrients by broilers fed on maize-soybean meal-based diets can be improved by the use of a combination of xylanase, amylase, protease and phytase. The nature of the diet (among others, particle size, pellet or mash) may influence nutrient digestibility and regulate response to exogenous enzymes.

The slight increase in the populations of total anaerobic bacteria and lactobacilli in the ileum of birds fed on a high MIL diet with supplemental enzyme may suggest a positive effect of substrate availability for microbial growth, especially at a higher maize level. There was a slight increase in the number of $C$. perfringens in the ileum and caeca. Clostridium perfringens is considered the causative agent of necrotic entiritis and is a very active species in the hydrolysis of bile salts (Knarreborg et al., 2002), which may depress broiler performance (Engberg et al., 2000). However, in this study, there was no incidence of necrotic entiritis.

\section{Conclusions}

In summary, the relatively higher level of maize (MM or HM) in diets caused a large and significant increase in FI (at a later age), LW and better FCR, although not to breed standards. The microbial enzyme supplementation resulted in a significant increase in these variables, but no change in FCR. Higher MIL had a positive effect on the relative weights of the small intestine, liver, proventriculus/gizzard and on intestinal $\mathrm{pH}$, but had no effect on other visceral organs. Enzyme addition enhanced only the relative weight of the liver.

The results suggest that maize grain responds positively to appropriate exogenous enzymes. It may, however, be necessary to test these enzyme products on more practical diets.

\section{Acknowledgement}

This project was financially supported by the University of New England, Australia, and Danisco Animal Nutrition, UK.

\section{References}

Almirall, M., Francesch, M., Perez-Vendrell, A.M., Brufau, J. \& Esteve-Garcia, E., 1995. The differences in intestinal viscosity produced by barley and beta-glucanase alter digesta enzyme activities and ileal nutrient digestibilities more in broiler chicks than in cocks. J. Nutr. 125, 947-955.

Annison, G., 1992. Commercial enzyme supplementation of wheat-based diets raises ileal glycanase activities and improves apparent metabolizable energy, starch and pentosan digestibilities in broiler chickens. Anim. Feed Sci. Technol. 38, 105-121.

Apajalahti, J., Kettunen, A. \& Graham, H., 2004. Characteristics of gastrointestinal microbial communities with special reference to the chicken. Wrld's Poult. Sci. J. 60, 223-232.

Bedford, M.R. \& Morgan, A.J., 1996. The use of enzymes in poultry diets. Wrld's Poult. Sci. J. 52, 61-68. 
Bedford, M.R. \& Schulze, H., 1998. Exogenous enzymes for pig and poultry. Nutr. Res. Rev. 11, 91-114.

Bedford, M.R., Classen, H.L. \& Campbell, G.L., 1991. The effect of pelleting, salt, and pentosanase on the viscosity of intestinal contents and the performance of broilers fed rye. Poult. Sci. 70, 1571-1577.

Bradford, M., 1976. A rapid and sensitive method for the quantitation of microgram quantities of protein utilizing the principle of protein-dye binding. Anal. Biochem. 72, 248-254.

Bradford, M., 1996. Interaction between ingested feed and the digestive system in poultry. J. App. Poult. Res. 5, 86-95.

Café, M.B., Borges, C.A., Fritts, C.A. \& Waldroup, P.W., 2002. Avizyme improves performance of broilers fed corn-soyabean meal based diets. J. App. Poult. Res. 11, 29-33.

Chesson, A., 2001. Non-starch polysaccharide degrading enzymes in poultry diets: Influence of ingredients on the selection of activities. Wrld's Poult. Sci. J. 57, 251-263.

Choct, M., 2006. Enzymes for the feed industry: past, present and future. Wrld's Poult. Sci. J. 62, 5-15.

Choct, M. \& Hughes, R.J., 1999. Effect of storage on the nutritive value of cereal grains for poultry. Proceedings of the $11^{\text {th }}$ Australian Poultry and Feed Convention, Gold Coast, Australia, 233-239.

Choct, M., Hughes, R.J., Trimble, R.P., Angkanaporn, K. \& Annison, G., 1995. Non-starch polysaccharidedegrading enzymes increase the performance of broiler chickens fed wheat of low apparent metabolizable energy. J. Nutr. 125, 485-492.

Choct, M., Hughes, R.J. \& Bedford, M.R., 1999. Effects of a xylanase on individual bird variation, starch digestion throughout the intestine, and ileal and caecal volatile fatty acid production in chickens fed wheat. Br. Poult. Sci. 40, 419-422.

Cowieson, A.J., 2005. Factors that affect the nutritional value of maize for broilers. Anim. Feed Sci. Technol. 119, 293-305.

Cowieson, A.J. \& Ravindran, V., 2008. Effect of exogenous enzymes in maize-based diets varying in nutrient density for young broilers: growth performance and digestibility of energy, minerals and amino acids. Br. Poult. Sci. 49, 37-44.

Cowieson, A.J., Singh, D.N. \& Adeola, O., 2006. Prediction of ingredient quality and the effect of a combination of xylanase, amylase, protease and phytase in the diets of broiler chicks. 1 . Growth performance and digestible nutrient intake. Br. Poult. Sci. 47, 477-489.

Douglas, M.W., Parsons, C.M. \& Bedford, M.R. 2000. Effect of various soyabean meal sources and avizyme on chick growth performance and ileal digestible energy. J. App. Poult. Res. 9, 74-80.

Duke, G.E., 1986. Alimentary canal: secretion and digestion, special digestive functions and absorption. In, Avian Physiology. Ed. Sturkie, P.D., Springer-Verlag, New York. pp. 289-302.

Engberg, R.M., Hedemann. M.S., Steenfeldt, S. \& Jensen, B.B. 2004. Influence of whole wheat and xylanase on broiler peroformance and microbial composition and acitivity in the digestive tract. Poult. Sci. 83, 925-938.

Engberg, R.M., Hedemann, M.S., Leser, T.D. \& Jensen, B.B., 2000. Effect of zinc bacitracin and salinomycin on intestinal microflora and performance of broilers. Poult. Sci. 78, 1311-1319.

Fathabadi, M.R., Dabiri, N. \& Mayahi, M., 2006. Effect of Avizyme enzyme addition to corn and soybean meal diets with different levels of enegry on broiler performance. Agri. Sci. Technol. 20, 81-90.

Gabriel, I., Mallet, S. \& Leconte, M., 2003. Differences in the digestive tract characteristics of broiler chickens fed on complete pelleted diet or on whole wheat added to pelleted protein concentrate. $\mathrm{Br}$. Poult. Sci. 44, 283-290.

Iji, P.A., Saki, A. \& Tivey, D.R., 2001. Body and intestinal growth of broiler chicks on a commercial starter diet. 2. Developement and characteristics of intestinal enzymes. Br. Poult. Sci. 42, 514-522.

Iji, P.A., Khumalo, K., Slippers, S. \& Gous, R.M., 2004. Intestinal function and body growth of broiler chickens on maize-based diets supplemented with mimosa tannins and a microbial enzyme. J. Sci. Food Agri. 84, 1451-1458.

Jiang, Z.Y., Zhou, Y.M., Lu FuZeng \& Han, Z.Y., 2008. Effects of different levels of supplementray aamylase on digetsive enzyme actitivites and pancreatic amylase mRNA expression of young broilers. Asian-Austr. J. Anim. Sci. 21, 97-102.

Jozeflak, D., Rutkowski, A., Jensen, B.B. \& Engberg, R.M., 2006. The effect of b-glucanase supplementation of barley and oat based diets on growth performance and fermentation in broiler chicken gastrointestinal tract. Br. Poult. Sci. 47, 57-64. 
Knarreborg, A., Engberg, R.M., Jensen, S.K. \& Jensen, B.B., 2002. Quantitative determination of bile salt hydrolase activity in bacteria isolated from the small intestine of chickens. Appl. Environ. Microbiol. 68, 6425-6428.

Mcpherson, G.A., 1985. Lowry program: Elsevier-BIOSOFT, 68 Hills Rd, Cambridage, CB2, 1LA, UK.

Miller, T.L. \& Wolin, M.J., 1974. A serum bottle modification of the hungate technique for cultivating obligate anaerobes. Appl. Environ. Microbiol. 27, 985-987.

Morris, T.R., 1998. Experimental Design and Analysis in Animal Sciences. University of Reading, Department of Agriculture, Reading, UK.

National Health and Medical Research Council, 1990. Australian Code of Practice for the care and use of animals for scientific purposes, Commonweath Scientific and Industrial Research Organisation, Australian Agricultural Council (Australian Govt. Pub. Service). Canberra, National Health and Medical Research Council.

Nitsan, Z., Dror, Y., Nir, I. \& Shapira, I., 1974. The effects of force-feeding on enzymes of the liver, kidney, pancreas and digestive tract of chicks. Br. J. Nutr. 32, 241-247.

Powell, S., Bidner, T.D. \& Southern, L.L., 2010. Phytase restores growth performance and bone characteristics in 0 to 21 day broilers fed varying levels of dietary calcium. Feedinfo News Service, Publised on Wednesday, 3rd March 2010.

Saleh, S.Y., Attia, K.A., ABD El-Hamid, S.S. \& Nassar, M.M., 2006. A comparative study on the effects of multi-enzyme feed additives "Kemzyme" on some fertility parameters of turkey toms and cockerels. Avian Poult. Biol. Rev. 17, 1470-1478.

Scott, T.A., Silversides, F.G. \& Zijlstra, R.T., 2003. Effect of pelleting and enzyme supplementation on variation in feed value of wheat-based diets fed to broiler chicks. Can. J. Anim. Sci. 83, 257-263.

Serviere-Zaragoza, E., Navarrete Del Toro, M.A. \& Garcia Carreno, F.L., 1997. Protein-hydrolyzing enzymes in the digestive system of the adult Mexican blue abalone, Haliotis fulgens (Gastropoda). Aquaculture 157, 325-336.

Shakouri, M.D., Iji, P.A., Mikkelsen, L.L. \& Cowieson, A.J., 2008. Intestinal function and gut microflora of broiler chickens as influenced by cereal grains and microbial enzyme supplementation. J. Anim. Physiol. Anim. Nutr. 93, 647-658.

Shirazi-Beechey, S.P., Smith, M.W., Wang, Y. \& James, P.S., 1991. Postnatal development of lamb intestinal digestive enzymes is not regulated by diet. J. Physiol. 437, 691-698.

Short, F.J., Gorton, P., Wiseman, J. \& Boorman, K.N., 1996. Determination of titanium dioxide added as an inert marker in chicken digestibility studies. Anim. Feed Sci. Technol. 59, 215-221.

Sklan, D. \& Noy, Y., 2000. Hydrolysis and absorption in the small intestines of posthatch chicks. Poult. Sci. 79, 1306-1310.

SPSS Inc., 2009. Version 17.0.0. SPSS Inc.,Chicago, USA.

Tony, M.A., Meeusen, A. \& Abdellatif, H.A., 2007. Effect of multi-enzyme systems with increasing levels of protease activity on broiler performance. In: Proceedings of $16^{\text {th }}$ European Symposium on Poultry Nutrition, Strasbourg, France, 629-632.

Uni, Z., Ganot, S. \& Sklan, D., 1998. Posthatch development of mucosal function in the broiler small intestine. Poult. Sci. 77, 75-82.

Uni, Z., Noy, Y. \& Sklan, D., 1999. Posthatch development of small intestinal function in the poult. Poult. Sci. 78, 215-222.

Yang, Y., Iji, P.A., Kocher, A., Mikkelsen, L.L. \& Choct, M., 2008. Effects of xylanase on growth and gut development of broiler chickens given a wheat-based diet. Asian-Austr. J. Anim. Sci. 21, 1659-1664.

Zarghi, H. \& Golian, A., 2009. Effect of triticale replacement and enzyme supplementation on performance and blood chemistry of broiler chickens. J. Anim. Vet. Advan. 8, 1316-1321. 